\title{
Peramalan Strategi Pelanggan serta Perpindahan Pelanggan Indomaret dan Alfamart dengan Metode Game Theory dan Markov Chain
}

\author{
Muhammad Aliwafa ${ }^{1 *}$, Sukanta $^{2}$, Rianita Puspa Sari ${ }^{3}$ \\ 1,2,3 Teknik Industri, Universitas Singaperbangsa Karawang, Karawang \\ *Koresponden email: 1710631140112@ student.unsika.ac.id
}

Diterima: 31 Agustus 2021

Disetujui: 30 September 2021

\begin{abstract}
Karawang is one of the areas that developed into one of the largest industrial cities in Indonesia. Karawang experienced rapid growth, especially in the industrial and commercial sectors. This has led to the occurrence of the change of the pattern of life in the community, so that modern society become identical with a consumptive lifestyle. Leads to the new needs that actually put forward in public life, one of which is the demand needs of life, especially basic needs. That's what became the basis of the number of franchise mini market opened, but there are two big names that are often visited by the people that Indomaret and Alfamart. The purpose of this study is to analyze the probability of the displacement of the consumer between two mini market. The method of game theory used for the analysis of customer strategy of the two-mini market, while the Markov chain is used to analyze the displacement of the customer. Results from game theory such Alfamart winning strategy on price and Indomaret winning strategy on the completeness of the product. While the results from the Markov chain there is a movement of consumers from Indomaret to Alfamart.
\end{abstract}

Keywords: Karawang, operation research, Markov Chain, game theory, customer strategy

\section{Abstrak}

Karawang merupakan salah satu daerah yang berkembang menjadi salah satu kota industri terbesar di Indonesia. Karawang mengalami pertumbuhan yang pesat, khususnya pada sektor industri dan komersial. Hal ini telah menyebabkan terjadinya perubahan pola hidup di masyarakat, sehingga masyarakat modern menjadi identik dengan pola hidup yang konsumtif. Mengarah pada kebutuhan baru yang sebenarnya dikedepankan dalam kehidupan masyarakat, salah satunya adalah permintaan akan kebutuhan hidupnya terutama kebutuhan pokok. Hal itulah yang menjadi dasar banyaknya franchise mini market yang dibuka, tetapi ada dua nama besar yang sering dikunjungi oleh masyarakat yaitu Indomaret dan Alfamart. Tujuan penelitian ini adalah menganalisa probabilitas perpindahan konsumen antar dua mini market tersebut. Metode game theory digunakan untuk analisis strategi pelanggan dari dua mini market tersebut, sedangkan Markov chain digunakan untuk menganalisis perpindahan pelanggan. Hasil dari game theory tersebut Alfamart memenangkan strategi pada harga dan Indomaret memenangkan strategi pada kelengkapan produk. Sedangkan hasil dari Markov chain terjadi perpindahan konsumen dari Indomaret ke Alfamart.

Kata Kunci: Karawang, riset operasi, Rantai Markov, teori permainan, strategi pelanggan

\section{Pendahuluan}

Pada era globalisasi ini mengakibatkan perubahan pada pola hidup sosial dan gaya hidup di masyarakat dengan perilaku yang cenderung konsumtif yang serba instan. Dengan perilaku konsumtif inilah yang mendorong munculnya industri yang memenuhi kebutuhan masyarakat, khususnya untuk memenuhi kebutuhan pokok. Karawang telah menjadi salah satu kota industri terbesar di Indonesia, dengan mayoritas penduduknya adalah pekerja kantoran, dimana mereka memiliki waktu yang terbatas untuk berbelanja memenuhi kebutuhan pokok hidupnya. Mereka lebih sering berbelanja untuk memenuhi kebutuhan hidup di mini market daripada pergi ke pusat perbelanjaan besar yang membutuhkan waktu luang yang cukup banyak, hal tersebut terjadi karena lokasi mini market lebih dekat dengan tempat tinggal dan memiliki harga yang cukup bersaing, sehingga minat beli pada mini market di Karawang menjadi tinggi.

Kondisi inilah yang menyebabkan banyak pelaku usaha franchise mini market yang membuka usahanya di Karawang, seperti Indomaret dan Alfamart yang paling banyak dibuka, walaupun masih ada mini market lainnya. Pada era seperti ini, membangun sebuah bisnis franchise menjadi sangat mudah, hal ini tidak terlalu memerlukan banyak aturan juga keterampilan yang luar biasa, karena sistem bisnis ini 
pemilik (franchisor) tinggal memberikan hak pada penerima hak waralaba (franchise) untuk dapat memanfaatkan hak atas kekayaan intelektual atau penemuan yang dimiliki oleh pemilik franchise melalui suatu perjanjian. Saking banyak penggemarnya dalam bisnis ini tentu saja hal ini memicu ketatnya persaingan antara dua mini market tersebut. Hal ini juga menuntut perusahaan tersebut untuk berinovasi dalam beberapa strategi pelanggan demi keberlangsungan usahanya. Karena jika hal tersebut tidak dilakukan akan mengakibatkan fenomena perpindahan merek di kalangan pelanggan atau dikenal dengan istilah brand switching. Perpindahan merek atau brand switching merupakan proses dimana konsumen beralih berdasarkan penggunaan satu produk ke produk lain akan tetapi berdasarkan kategori yang sama [1]. Oleh karenanya perusahaan diharuskan memiliki strategi terutama marketing yang jitu supaya dapat memenangkan persaingan yang cukup ketat. Strategi pelanggan merupakan perencanaan untuk membuat suatu hubungan yang berurusan dengan para pelanggan, namun siapapun yang menjalankan sebuah bisnis akan memberitahu bahwa para pelanggan tidaklah sederhana [2]. Strategi pelanggan yang digunakan adalah dalam hal pelayanan, harga, dan kelengkapan produk.

Markov chain adalah suatu metode yang dipakai untuk peramalan market share pada periode sekarang menjadi landasan untuk peramalan market share kedepannya [3]. Untuk memperoleh strategi pelanggan yang tepat dalam menghadapi persaingan maka dapat diberlakukan perhitungan secara probabilitas dengan metode game theory. Kembali lagi hal tersebut dilakukan guna mengetahui strategi pelanggan apa yang paling baik untuk diterapkan.

Semua hal tersebut dilakukan untuk memenangi persaingan, akan tetapi yang menjadi syarat wajib suatu industri supaya mampu memenangi kompetisi ialah berjuang menggapai intensi untuk mendatangkan dan menjaga jumlah pelanggan [4]. Strategi pelanggan dapat menumbuhkan kepuasan pelanggan, sedangkan kepuasan pelanggan itu sendiri berdampak pada loyalitas pelanggan. Loyalitas pelanggan merupakan suatu kekuatan hubungan antara suatu sikap relatif antar individu terhadap suatu kesatuan dalam hal ini bisa menjadi merek, jasa, toko, ataupun pemasok dan melakukan pembelian ulang [5]. Selain itu loyalitas merupakan suatu mekanisme, dimana mekanisme tersebut menghasilkan suatu kepuasan, kepuasan memiliki dampak pada penilaian persepsi yang mampu berdampak pada loyalitas serta niat untuk karakter tertentu yang diciptakan oleh pelanggan [6]. Jika kepuasan pelanggan dapat menimbulkan loyalitas pelanggan maka sebaliknya ketidakpuasan pelanggan akan menimbulkan perpindahan pelanggan.

Dari penelitian terdahulu bahwa ketidakpuasan pelanggan dapat mempengaruhi terhadap perpindahan pelanggan, variabel dari kebutuhan akan mencari variasi tidak dapat memoderasi hubungan dengan ketidakpuasan terhadap perpindahan pelanggan, ketika pelanggan sedang mengalami ketidakpuasan meskipun tidak disertai dorongan dari kebutuhan akan mencari suatu variasi meka keputusan untuk berpindah masih tetap tinggi [7]. Selain itu ada juga faktor-faktor lain yang dapat menyebabkan perpindahan pelanggan. Meminimasi perpindahan pelanggan menjadi salah satu target utama dari perusahaan-perusahaan.

Ada dua macam strategi optimum yang dapat dipakai oleh tiap-tiap pemain, yaitu pure strategy (strategi murni) dan mixed strategy (strategi campuran). Pada permainan strategi murni, strategi yang optimal untuk tiap-tiap pemain adalah dengan memakai strategi tunggal. Solusi yang dihasilkan dari metode game theory menggunakan kriteria maksimin dan minimaks. Maximizing player (pemain baris) mengidentifikasi strategi optimalnya melalui kriteria maksimin. Sedangkan minimizing player (pemain kolom) sebaliknya, yaitu menggunakan kriteria minimaks untuk identifikasi strategi optimalnya. Dalam hal ini nilai yang wajib dicapai adalah maksimum berdasarkan minimaks baris \& minimum berdasarkan maksimin kolom sekaligus. Solusi yang dihasilkan berdasarkan model akan menghasilkan total manfaat bagi pemain yang optimal [8]. Sedangkan apabila pure strategy (strategi murni) belum tercapai, maka mixed strategy (strategi campuran) digunakan, dimana strategi dari tiap-tiap pemain akan memiliki probabilitas yang memperlihatkan proporsi dari banyaknya bagian yang terpakai untuk menjalankan taktik tersebut [9].

Penelitian ini bertujuan untuk mengetahui pengaruh dari strategi pelanggan terhadap tingkat perpindahan pelanggan dan juga strategi pelanggan yang diterapkan untuk memenangkan persaingan dari kedua mini market tersebut. Salah satu cara yang digunakan untuk mengetahui tingkat perpindahan pelanggan mini market di daerah Karawang tersebut menggunakan metode Markov chain, dan strategi pelanggan untuk memenangkan persaingan dalam perpindahan pelanggan dapat diidentifikasi dengan metode game theory. Dari penelitian ini juga dapat dilihat persentase perpindahan pelanggan dari kedua mini market tersebut selama periode penelitian berlangsung.

Jadi dengan kedua metode tersebut dapat diketahui bahwa strategi pelanggan mana yang paling bagus untuk diterapkan diantara pelayanan, harga, dan kelengkapan produk. Yang akan memiliki dampak terhadap perpindahan pelanggan setiap tahunnya. Perpindahan pelanggan ini jika tidak ditangani secara serius dapat berpengaruh terhadap perkembangan perusahaan. Maka dari itu salah satu tujuan dari 
penelitian ini adalah meramalkan perpindahan pelanggan dalam 5 tahun (periode) ke depan apabila strategi konsumen tidak mengalami perubahan yang dilakukan oleh perusahaan. Penelitian ini dilakukan pada beberapa gerai Indomaret dan Alfamart yang terletak di Jl. HS. Ronggo Waluyo, Puseurjaya, Telukjambe Timur, Kabupaten Karawang, Jawa Barat. Dengan melakukan sampling terhadap pengguna kedua mini market pada daerah tersebut.

\section{Metode Penelitian}

Pada penelitian ini digunakan pendekatan kuantitatif dengan didasarkan dari tujuan penelitian ini masuk ke dalam kategori penelitian korelasional. Kategori ini yaitu penelitian yang memiliki keterlibatan terhadap pengumpulan data untuk dapat menentukan apakah, dan sejauh mana, ada hubungan yang dimiliki oleh dua atau lebih variabel yang dapat dihitung [10]. Dari manfaat yang dihasilkan, penelitian ini ialah penelitian terapan. Penelitian terapan adalah salah satu macam dari penelitian yang bertujuan untuk menghasilkan suatu jalan keluar dari permasalahan secara praktis [11].

\section{Kajian Pustaka}

Kajian pustaka adalah pengumpulan suatu data dan informasi-informasi ilmiah sebelumnya, seperti suatu teori, metode, maupun pendekatan-pendekatan yang berkembang dan telah diarsipkan dalam sebuah buku ataupun karya tulisan lainnya [12]

\section{Riset Operasi}

Riset Operasi (Operational Research) adalah suatu aplikasi dari metode, teknik, dan peralatan ilmiah untuk menghadapi persoalan-persoalan yang ada dalam sebuah operasi di perusahaan yang memiliki tujuan untuk memberikan solusi terhadap persoalan-persoalan tersebut dengan optimal [13]. Salah satu yang merupakan metode pada riset operasi adalah peramalan, sebagaimana yang digunakan dalam penelitian ini. Peramalan merupakan suatu perkiraan dari peristiwa-peristiwa pada waktu dimasa yang akan datang yang didasari oleh pola-pola yang terbentuk dimasa yang lalu. Peramalan bisa dilakukan dengan melibatkan pengambilan data-data dimasa lalu dan menempatkannya pada masa yang akan datang, dalam suatu bentuk model matematis [14]. Dengan peramalan yang baik dan tepat diharapkan nilai pemborosan-pemborosan akan bisa berkurang, dan dapat lebih terkonsentrasi kepada sasaran tertentu dengan perencanaan yang lebih baik sehingga dapat menjadi kenyataan.

\section{Game Theory}

Game theory ialah salah satu pendekatan sistem secara matematis yang digunakan untuk memformulasikan suatu situasi permasalahan serta persaingan diantara bermacam-macam kepentingan. Teori ini berkembang untuk memberikan analisa dari proses dalam pengambilan keputusan dari bermacammacam situasi persaingan yang berbeda serta melibatkan dua atau lebih kepentingan. Untuk menggunakan teori ini maka langkah awal yang harus dilakukan ialah dengan memilih secara tegas para pemain yang akan bermain, strategi yang digunakan, serta memilih pengutamaan serta tindakan dari tiap-tiap pemain.

Dalam game theory ini terbagi menjadi dua jenis strategi yang dapat digunakan, seperti yang telah dibahas sebelumnya. Ada pure strategy atau yang dikenal dengan strategi murni. Strategi ini biasanya digunakan untuk jenis permainan dengan hasil optimalnya mempunyai nilai saddle point. Sedangkan yang tidak memiliki nilai saddle point pada hasil optimalnya dinamakan mixed strategy atau strategi campuran. Selain itu pada game theory ini memiliki beberapa elemen dasar seperti:

a. Jumlah pemain. Permainan dapat dibagi menurut dari jumlah kepentingan atau tujuan yang ada pada permainan tersebut.

b. Pay-off. Ganjaran atau pay-off merupakan hasil akhir yang diperoleh pada akhir permainan, dapat digolongkan menjadi dua jenis yaitu permainan jumlah-nol (zero-sum games) \& permainan jumlah bukan-nol (non-zero-sum games).

c. Strategi permainan. Dalam teori ini adalah suatu cara tertentu dari seorang pemain sebagai reaksi dari aksi yang dilakukan oleh pesaingnya.

d. Matriks permainan. Merupakan sebuah matriks yang semua unsur berupa ganjaran-ganjaran dari para pemain yang bermain.

e. Saddle point. Merupakan suatu unsur dari matriks permainan yang sekaligus sebagai nilai maksimin dan minimaks kolom.

\section{Markov Chain}

Markov chain merupakan metode yang mempelajari sifat dari suatu variabel pada masa kini yang berlandaskan dari sifat variabel itu sendiri dimasa lalu yang akan digunakan untuk meramal sifat dari variabel dimasa depan. Teori ini biasa digunakan untuk melakukan pembuatan model dari bermacam- 
macam sistem dan proses bisnis. Teori ini masuk ke dalam kategori proses stokastik. Dalam teori ini memiliki beberapa sifat umum. Sifat umum dari proses Markov itu sendiri adalah:

$$
\begin{aligned}
& f(X n \mid X n-1, \ldots, X 1)=f(X n \mid X n-1) \\
& E\{X n \mid X n-1, \ldots, X 1\}=E\{X n \mid X n-1\} \\
& f(X n \mid X n+1, \ldots, X n+k)=f(X n \mid X n+1) \\
& f(X n, X k \mid X m)=f(X n \mid X m) f(X k \mid X m)
\end{aligned}
$$

Dalam teori ini juga terdapat beberapa asumsi-asumsi atau anggapan dasar yang harus diketahui. Yang pertama, jumlah dari probabilitas transisi keadaan ialah 1. Dimana probabilitas transisi tidak akan mengalami perubahan. Dan probabilitas transisi hanya tergantung pada status sekarang, bukan dari periode sebelumnya.

\section{Uji Validitas}

Validitas berasal dari bahasa Inggris yaitu validity yang memiliki arti sebuah ukuran yang memberikan petunjuk bahwa variabel yang diukur memang berdasarkan dari kebenaran variabel yang hendak diteliti oleh peneliti [15]. Jadi uji validitas ialah sebuah tolak ukur untuk menguji yang dijadikan sebagai petunjuk dari alat ukur yang digunakan dalam pengukuran mengukur sejauh mana objek yang akan diukur. Suatu tes dapat dikatakan valid apabila memiliki nilai validitas yang tinggi jika tes tersebut menjalankan fungsi ukurnya, atau memberikan hasil ukur yang tepat dan akurat sesuai dengan maksud diadakannya tes tersebut.

Untuk melakukan uji validitas ini menggunakan software Statistic Product and Service Solution (SPSS). Teknik pengujian dengan menggunakan teori bivariate pearson. Analisis ini dihitung dengan cara mengkorelasikan masing-masing dari skor item dan skor total yang diperoleh. Item-item dari pertanyaan yang berkorelasi signifikan dengan skor total menunjukkan item-item tersebut mampu memberikan dukungan dalam mengungkap apa yang ingin diungkap. Dapat dinyatakan valid apabila $r$-hitung $\geq r$-tabel.

\section{Uji Reabilitas}

Reabilitas berasal dari kata reability yang memiliki arti keandalan suatu pengukuran [16]. Jadi uji reabilitas ialah sejauh mana hasil pengukuran suatu tes konsisten ketika subjek diuji berulang kali dan dengan kondisi yang sama. Dalam melakukan uji ini menggunakan software Statistic Product and Service Solution (SPSS). Pengujian reabilitas instrumen dengan menggunakan rumus cronbach alpha karena instrumen penelitian ini berbentuk angket dan skala bertingkat. Dapat dinyatakan reliable apa bila nilai dari rxx mendekati angka 1, atau sudah cukup memuaskan jika $\geq 0,700$.

\section{Sample}

Sampel dilakukan dengan menggunakan kuesioner dengan media online yaitu google form. Teknik yang digunakan untuk penyebaran kuesioner ini adalah teknik convenience sampling. Convenience sampling adalah suatu metode yang digunakan untuk menentukan sampel dengan cara memilih sampel dengan acak sesuai dengan kehendak dari peneliti [17]. Sampel diambil dari beberapa pengguna Indomaret dan Alfamart yang terletak di Jl. HS. Ronggo Waluyo, Puseurjaya, Telukjambe Timur, Kabupaten Karawang. Jumlah minimum sampel pada penelitian ini yaitu 10 kali dari jumlah indikator terbanyak dari salah satu variabel [18]. Sehingga perhitungan jumlah sampel pada penelitian ini adalah sebagai berikut:

$$
\begin{aligned}
N & =j u m l a h \text { indikator terbanyak } \times 10 \\
& =3 \times 10 \\
& =30 \text { sampel }
\end{aligned}
$$

Berdasarkan perhitungan di atas sampel minimum pada penelitian ini sebanyak 30 sampel. Akan tetapi peneliti mengambil sampel sebanyak 35 sampel.

\section{Tahapan Penelitian}

Penelitian ini mempunyai beberapa tahapan dengan melakukan studi kepustakaan baik dari jurnal ataupun buku. Dari sumber literatur pertama dilakukan penelitian pendahuluan untuk mengetahui variabel apa saja yang dipakai pada penelitian lebih lanjut. Variabel dari penelitian tadi diteliti bagaimana hubungan $\&$ interaksi satu dengan lainnya. Setelah mengumpulkan beberapa studi literatur, maka dilakukan penelitian pendahuluan, hal ini digunakan untuk memperoleh variabel dan atribut penelitian yang dibutuhkan. Kemudian mulai merumuskan masalah, tujuan penelitian dan juga kerangka konseptual yang dilakukan serta instrumen penelitian. Pengumpulan data dilakukan dengan penyebaran kuesioner, kemudian dilakukan pengujian validitas dan reabilitas dari data yang diperoleh. Jika data valid dan andal penelitian 
dilanjutkan ke tahap selanjutnya, jika belum maka ada beberapa pengulangan terhadap instrumen penelitian.

\section{Hasil dan Pembahasan}

Data Penelitian

Data penelitian diperoleh dari hasil kuesioner, terdapat 35 data yang telah dikumpulkan dari hasil kuesioner. Data tersebut dapat dilihat pada Tabel 1. Pada tabel tersebut memiliki beberapa variabel.

$\begin{array}{ll}\text { Indomaret } & X 1: \text { Pelayanan } \\ & X 2: \text { Harga } \\ & X 3: \text { Kelengkapan produk } \\ \text { Alfamart } & X 4: \text { Pelayanan } \\ & X 5: \text { Harga } \\ & X 6: \text { Kelengkapan produk }\end{array}$

Tabel 1. Data hasil kuesioner

\begin{tabular}{ccccccc}
\hline \multirow{2}{*}{ Data } & \multicolumn{5}{c}{ Indomaret } & \multicolumn{4}{c}{ Alfamart } \\
& X1 & X2 & X3 & X4 & X5 & X6 \\
\hline 01 & 3 & 3 & 4 & 3 & 3 & 3 \\
02 & 5 & 3 & 5 & 4 & 4 & 4 \\
03 & 3 & 2 & 4 & 3 & 3 & 2 \\
04 & 3 & 3 & 3 & 3 & 3 & 3 \\
05 & 4 & 3 & 4 & 3 & 4 & 2 \\
06 & 4 & 3 & 3 & 3 & 3 & 3 \\
07 & 4 & 4 & 5 & 5 & 4 & 5 \\
08 & 5 & 5 & 5 & 4 & 4 & 4 \\
09 & 5 & 5 & 5 & 5 & 5 & 5 \\
10 & 4 & 3 & 4 & 4 & 3 & 4 \\
11 & 3 & 3 & 3 & 3 & 3 & 3 \\
12 & 4 & 3 & 5 & 4 & 3 & 4 \\
13 & 4 & 3 & 3 & 3 & 3 & 3 \\
14 & 3 & 2 & 4 & 4 & 4 & 3 \\
15 & 4 & 4 & 4 & 4 & 4 & 4 \\
16 & 4 & 3 & 3 & 5 & 5 & 1 \\
17 & 4 & 4 & 5 & 3 & 4 & 3 \\
18 & 5 & 5 & 5 & 5 & 5 & 5 \\
19 & 4 & 3 & 4 & 3 & 4 & 3 \\
20 & 4 & 3 & 3 & 2 & 2 & 2 \\
21 & 2 & 4 & 4 & 5 & 5 & 5 \\
22 & 5 & 5 & 5 & 2 & 2 & 3 \\
23 & 3 & 5 & 4 & 3 & 5 & 4 \\
24 & 3 & 3 & 4 & 3 & 5 & 5 \\
25 & 3 & 3 & 4 & 5 & 5 & 5 \\
26 & 5 & 3 & 4 & 5 & 4 & 5 \\
27 & 4 & 4 & 5 & 5 & 5 & 4 \\
28 & 5 & 5 & 3 & 5 & 5 & 3 \\
29 & 5 & 4 & 3 & 4 & 5 & 3 \\
30 & 4 & 4 & 5 & 4 & 5 & 3 \\
31 & 3 & 3 & 4 & 3 & 5 & 4 \\
32 & 4 & 3 & 3 & 4 & 5 & 5 \\
33 & 4 & 3 & 5 & 5 & 4 & 3 \\
34 & 4 & 4 & 4 & 5 & 4 & 4 \\
35 & 5 & 5 & 4 & 5 & 5 & 3 \\
\hline & & Sumber: Kuesioner $(2019)$ & &
\end{tabular}

Sumber: Kuesioner (2019)

Rentang nilai yang digunakan adalah 1-5 dimana nilai tersebut menginterpretasikan nilai kepuasan pelanggan terhadap variabel tersebut, dimana nilai skalanya adalah:

$$
\begin{aligned}
& 1=\text { Tidak puas } \\
& 2=\text { Kurang puas } \\
& 3=\text { Biasa }
\end{aligned}
$$




$$
\begin{aligned}
& 4=\text { Puas } \\
& 5=\text { Sangat puas }
\end{aligned}
$$

Berdasarkan data pada Tabel 1 terdapat beberapa nilai untuk kepuasan pelanggan, yang pertama adalah dalam segi pelayanan. Pelayanan pada Indomaret $(X 1)$ mendapatkan nilai total sebesar 138, sedangkan pada Alfamart (X4) mendapatkan nilai total sebesar 136. Dari segi harga, pada Indomaret $(X 2)$ sendiri memperoleh nilai total sebesar 125, sedangkan pada Alfamart (X5) memperoleh nilai sebesar 142. Kelengkapan produk yang diberikan oleh Indomaret (X3) mendapatkan nilai total sebesar 142, sedangkan pada Alfamart (X6) sebesar 125.

Selain data pada Tabel 1, terdapat juga data perpindahan pelanggan selama dua periode. Data tersebut dapat dilihat pada Tabel 2. Tabel 2 tersebut terdapat perpindahan pelanggan Indomaret dan Alfamart yang diperoleh dari 35 responden. Sehingga dari data tersebut dapat digunakan untuk memprediksi perpindahan pelanggan dari dua sampai lima periode selanjutnya. Hal ini dibatasi hanya sampai periode ke lima dan jika perusahaan tidak mengubah strategi pelanggan.

\begin{tabular}{|c|c|c|}
\hline Data & Periode 1 & Periode 2 \\
\hline 01 & Indomaret & Alfamart \\
\hline 02 & Indomaret & Indomaret \\
\hline 03 & Alfamart & Alfamart \\
\hline 04 & Indomaret & Indomaret \\
\hline 05 & Alfamart & Alfamart \\
\hline 06 & Alfamart & Alfamart \\
\hline 07 & Indomaret & Alfamart \\
\hline 08 & Indomaret & Indomaret \\
\hline 09 & Indomaret & Indomaret \\
\hline 10 & Alfamart & Alfamart \\
\hline 11 & Indomaret & Indomaret \\
\hline 12 & Indomaret & Indomaret \\
\hline 13 & Indomaret & Indomaret \\
\hline 14 & Alfamart & Alfamart \\
\hline 15 & Indomaret & Alfamart \\
\hline 16 & Indomaret & Alfamart \\
\hline 17 & Indomaret & Indomaret \\
\hline 18 & Indomaret & Indomaret \\
\hline 19 & Alfamart & Alfamart \\
\hline 20 & Indomaret & Indomaret \\
\hline 21 & Alfamart & Alfamart \\
\hline 22 & Indomaret & Indomaret \\
\hline 23 & Indomaret & Alfamart \\
\hline 24 & Alfamart & Alfamart \\
\hline 25 & Alfamart & Alfamart \\
\hline 26 & Alfamart & Alfamart \\
\hline 27 & Indomaret & Alfamart \\
\hline 28 & Indomaret & Indomaret \\
\hline 29 & Indomaret & Indomaret \\
\hline 30 & Indomaret & Indomaret \\
\hline 31 & Alfamart & Alfamart \\
\hline 32 & Indomaret & Alfamart \\
\hline 33 & Alfamart & Alfamart \\
\hline 34 & Alfamart & Alfamart \\
\hline 35 & Indomaret & Indomaret \\
\hline
\end{tabular}

Tabel 2. Data perpindahan pelanggan

Dari Tabel 2 dapat diketahui bahwa terdapat perpindahan pelanggan dari Indomaret ke Alfamart sebanyak 7 orang. Sedangkan dari Alfamart ke Indomaret tidak ada perpindahan pelanggan selama dua periode tersebut. Dan sisa dari responden, masing-masing masih tetap bertahan pada pilihan mini market waralaba (franchise) favorit mereka masing-masing.

\section{Uji Validitas}


Uji validitas ini dihitung dengan menggunakan teknik korelasi pearson yang dibantu dengan software SPSS.

\begin{tabular}{|c|c|c|c|c|c|c|c|c|}
\hline \multicolumn{9}{|c|}{ Correlations } \\
\hline & & $\mathrm{x} 1$ & $x 2$ & $x 3$ & $\overline{X 4}$ & $\times 5$ & $\times 6$ & TOTAL \\
\hline \multirow[t]{3}{*}{$\overline{\mathrm{X} 1}$} & Pearson Correlation & 1 & $.504^{\prime \prime}$ & .245 & .258 & .044 & .005 & $.494^{4 \prime}$ \\
\hline & Sig. (2-tailed) & & .002 & .156 & .135 & .804 & .977 & .003 \\
\hline & $\mathrm{N}$ & 35 & 35 & 35 & 35 & 35 & 35 & 35 \\
\hline \multirow[t]{3}{*}{$X_{2}$} & Pearson Correlation & $.504^{1-}$ & 1 & $.342^{\circ}$ & .286 & $.350^{\circ}$ & .275 & $696^{21}$ \\
\hline & Sig. (2-tailed) & .002 & & .044 & .096 & 039 & .110 & .000 \\
\hline & $\mathrm{N}$ & 35 & 35 & 35 & 35 & 35 & 35 & 35 \\
\hline \multirow[t]{3}{*}{$x_{3}$} & Pearson Correlation & .245 & $.342^{\circ}$ & 1 & .249 & .118 & $.366^{\circ}$ & $.569^{21}$ \\
\hline & Sig. (2-tailed) & .156 & .044 & & .150 & .498 & .031 & .000 \\
\hline & $\mathrm{N}$ & 35 & 35 & 35 & 35 & 35 & 35 & 35 \\
\hline \multirow[t]{3}{*}{$x_{4}$} & Pearson Correlation & .258 & .286 & .249 & 1 & $626^{\prime \prime}$ & $.421^{\circ}$ & $.753^{\prime \prime}$ \\
\hline & Sig. (2-tailed) & .135 & .096 & .150 & & .000 & .012 & .000 \\
\hline & $\mathrm{N}$ & 35 & 35 & 35 & 35 & 35 & 35 & 35 \\
\hline \multirow[t]{3}{*}{$\times 5$} & Pearson Correlation & .044 & $.350^{\circ}$ & .118 & $.626^{\circ}$ & 1 & $.389^{\circ}$ & $679^{\circ \prime}$ \\
\hline & Sig. (2-tailed) & .804 & .039 & .498 & .000 & & .021 & .000 \\
\hline & $\mathrm{N}$ & 35 & 35 & 35 & 35 & 35 & 35 & 35 \\
\hline \multirow[t]{3}{*}{$x 6$} & Pearson Correlation & .005 & .275 & $366^{\circ}$ & $421^{\circ}$ & $.389^{\circ}$ & 1 & $667^{\prime \prime}$ \\
\hline & Sig. (2-tailed) & .977 & .110 & .031 & .012 & .021 & & .000 \\
\hline & $\mathrm{N}$ & 35 & 35 & 35 & 35 & 35 & 35 & 35 \\
\hline \multirow[t]{3}{*}{ TOTAL } & Pearson Correlation & $494^{\prime \prime}$ & $.696^{\prime \prime}$ & $.569^{\prime \prime}$ & $.753^{\prime \prime}$ & $.679^{\circ}$ & $.667^{\circ \prime}$ & 1 \\
\hline & Sig. (2-tailed) & .003 & .000 & .000 & .000 & .000 & .000 & \\
\hline & $\mathrm{N}$ & 35 & 35 & 35 & 35 & 35 & 35 & 35 \\
\hline
\end{tabular}

Gambar 1. Hasil uji validitas korelasi pearson Sumber: SPSS (2021)

Seperti yang sudah dibahas pada kajian pustaka bahwa pada uji validasi dikatakan valid apabila $r$ hitung $\geq r$-tabel, dan jika $r$-hitung $<r$-tabel maka dikatakan tidak valid. Validitas setiap variabel ditunjukkan oleh kolom TOTAL. Berdasarkan $\mathrm{r}$ tabel, nilai Pearson correlation minimal adalah 0.3338, karena menggunakan 35 responden maka nilai $d f=(N-2)$ yaitu 33, jadi dilihat pada tabel $\mathrm{r}$ dengan nilai $d f$ = 33 dan tingkat signifikasi sebesar 0,05 atau sebesar 5\%. Dapat dilihat pada Gambar 1 nilai pada kolom TOTAL nilainya $(r$-hitung $)>0,3338$, sehingga data tersebut sudah valid.

\section{Uji Reabilitas}

Uji reabilitas dihitung dengan software SPSS. Suatu pengukuran yang memiliki reabilitas atau keandalan yang tinggi disebut sebagai pengukuran yang reliabel (reliable).

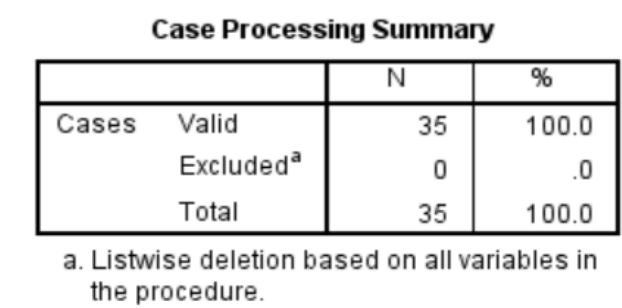

Gambar 2. Hasil case processing summary Sumber: SPSS (2021)

Dari hasil case processing summary pada Gambar 2 menunjukkan total kasus yang diujikan dan banyaknya nilai kasus yang valid. Untuk hasil yang valid sebesar 35 dengan persentase $100 \%$. Dimana dari keseluruhan data responden sudah valid. Hasil dari reability dengan cronbach's alpha untuk menentukan apakah data penelitian sudah reliable atau belum dapat dilihat pada Gambar 3.

\section{Reliability Statistics}

\begin{tabular}{|r|r|}
\hline $\begin{array}{c}\text { Cronbach's } \\
\text { Alpha }\end{array}$ & N of Items \\
\hline .721 & 6 \\
\hline
\end{tabular}

Gambar 3. Hasil reability statistics Sumber: SPSS (2021) 
Reliability statistics menunjukkan hasil analisis dari uji reliabilitas dengan cronbach's alpha. Nilai reliabilitas sebesar 0,721 adalah nilai moderat dan $>0,700$. sehingga data ini bisa dikatakan konsisten (reliable).

\section{Game Theory}

Dalam analisa dengan menggunakan metode game theory dibutuhkan data hasil dari rekapitulasi nilai jenis strategi pelanggan dari kuesioner kepuasan pelanggan Indomaret dan Alfamart. Dari data yang telah diperoleh dari Tabel 3 dan Tabel 4, kemudian dimasukkan kedalam matriks payoff untuk selanjutnya dilakukan perhitungan dengan menggunakan metode game theory.

Tabel 3. Data rekapitulasi nilai Indomaret

\begin{tabular}{ll}
\hline Jenis Strategi & Total \\
\hline Pelayanan (X1) & 138 \\
Harga (X2) & 125 \\
Kelengkapan Produk (X3) & 142 \\
\hline
\end{tabular}

Sumber: Kuesioner (2019)

Tabel 4. Data rekapitulasi nilai Alfamart

\begin{tabular}{ll}
\hline Jenis Strategi & Total \\
\hline Pelayanan (X4) & 136 \\
Harga (X5) & 142 \\
Kelengkapan Produk (X6) & 125 \\
\hline
\end{tabular}

Sumber: Kuesioner (2019)

Perhitungan ini dibantu dengan software POM-QM for Windows. Pada Gambar 4 merupakan perhitungan matriks payoff. Adapun untuk menentukan matrik payoff digunakan rumus sebagai berikut:

$$
X_{i} X_{j}=\text { Strategi Baris }- \text { Strategi Kolom }
$$

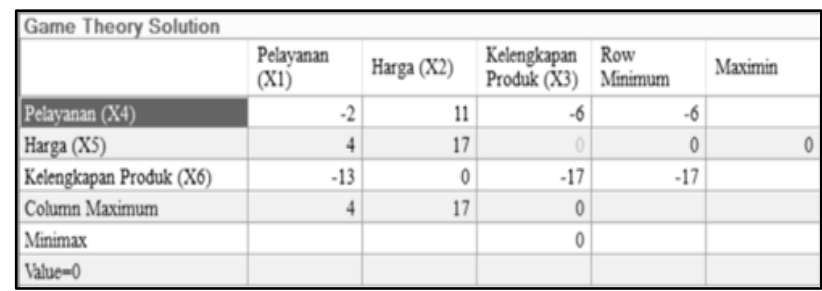

Gambar 4. Hasil matrix payoff

Sumber: POM-QM (2021)

Dengan metode yang digunakan yakni maximin dan minimax, saddle point pada matriks payoff telah diketahui, yakni terletak pada harga dan kelengkapan produk karena nilai saddle point yang diperoleh telah sama yakni 0 maka dapat dikatakan bahwa perhitungan ini telah optimal. Karena nilai yang didapatkan optimal dan memiliki saddle point maka jenis strategi permainan (game theory) yang digunakan adalah pure strategy atau strategi murni. Pada gambar selanjutnya yaitu Gambar 5, dalam gambar tersebut terdapat hasil strategi yang memenangkan permainan. Hasil tersebut didapatkan dari hasil matriks payoff yang sudah dihitung sebelumnya.

\begin{tabular}{|l|r|}
\hline Game Theory Solution \\
\hline ROW \\
\hline Pelayanan (X4) & 0 \\
\hline Harga (X5) & 1 \\
\hline Kelengkapan Produk (X6) & 0 \\
\hline COLUMN & \\
\hline Pelayanan (X1) & 0 \\
\hline Harga (X2) & 0 \\
\hline Kelengkapan Produk (X3) & 1 \\
\hline
\end{tabular}

Gambar 5. Hasil strategi pelanggan

Sumber: POM-QM (2021) 
Berdasarkan Gambar 5 diketahui bahwa hasil strategi pelanggan dengan POM-QM yaitu Indomaret memenangkan strategi pelanggan pada kelengkapan produk (X3), sedangkan Alfamart memenangkan strategi pelanggan pada harga (X5). Dari hasil tersebut perusahaan dapat membuat evaluasi terhadap strategi pelanggan nya masing-masing supaya dapat menumbuhkan loyalitas pelanggan dan mendapat sasaran pelanggan baru.

\section{Markov Chain}

Pada analisis ini digunakan untuk memprediksi perpindahan pelanggan dari kedua mini market tersebut. Dapat dilihat pada Tabel 5 rekapitulasi data dari perpindahan pelanggan selama dua periode. Data ini dibutuhkan untuk memprediksi perpindahan pelanggan pada periode ketiga sampai kelima, peneliti memberi batasan hanya sampai pada periode kelima saja. Dengan batasan jika tidak adanya perubahan strategi pelanggan pada masing-masing perusahaan, supaya bisa diketahui dampak yang bisa saja terjadi dari perpindahan pelanggan jika perusahaan tidak mengubah strategi pelanggan tersebut. Pada Tabel 6 merupakan persentase dari pangsa awal (periode 1) dari kedua perusahaan Indomaret dan juga Alfamart.

Tabel 5. Data rekapitulasi perpindahan pelanggan

\begin{tabular}{ccccc}
\hline & \multirow{2}{*}{ Periode 1 } & \multicolumn{2}{c}{ Menuju } & Periode \\
& & Indomaret & Alfamart & 2 \\
\hline Indomaret & 22 & 15 & 7 & 15 \\
Alfamart & 13 & 0 & 13 & 20 \\
Total & 35 & & & 35 \\
\hline \multicolumn{5}{l}{ Sumber: Kuesioner (2019) }
\end{tabular}

Tabel 6. Data persentase pelanggan periode 1

\begin{tabular}{cccc}
\hline \multirow{2}{*}{ No } & $\begin{array}{c}\text { Nama } \\
\text { Franchise }\end{array}$ & Jumlah Responden & $\begin{array}{c}\text { Persentase } \\
(\%)\end{array}$ \\
\hline 1. & Indomaret & 22 & $63 \%$ \\
2. & Alfamart & 13 & $37 \%$ \\
& Jumlah & 35 & $100 \%$ \\
\hline
\end{tabular}

Sumber: Kuesioner (2019)

Setelah diketahui pangsa awal (periode 1) dari kedua perusahaan Indomaret dan Alfamart, kemudian mencari kemungkinan responden melakukan perpindahan brand pada periode selanjutnya. Dapat diketahui dari Tabel 5 bahwa ada 7 orang responden yang pada periode 1 berkunjung ke Indomaret lalu pada periode selanjutnya mereka berpindah ke Alfamart. Sedangkan pada Alfamart pada periode selanjutnya tidak ada perpindahan pelanggan ke Indomaret.

Ketika sudah diketahui perpindahan pelanggan pada periode 1 ke periode 2 maka selanjutnya dapat dibuat dalam tabel probabilitas transisi pelanggan yang melakukan perpindahan dari kedua mini market tersebut pada periode selanjutnya. Dalam Tabel 7 berisi tentang probabilitas transisi pelanggan tersebut. Rumus yang digunakan untuk menghitung probabilitas transisi pelanggan ini adalah sebagai berikut:

$$
P=\frac{\text { jumlah perpindahan pelanggan }_{n}}{\text { total pelanggan }_{n}}
$$

Tabel 7. Data probabilitas transisi pelanggan

\begin{tabular}{|c|c|c|c|c|}
\hline & \multirow[b]{2}{*}{ Dari } & \multicolumn{2}{|c|}{ Menuju } & \multirow{2}{*}{ Total } \\
\hline & & Indomaret & Alfamart & \\
\hline Indomaret & 22 & 0,68 & 0,32 & 1,00 \\
\hline Alfamart & 13 & 0 & 1,00 & 1,00 \\
\hline Total & 35 & & & \\
\hline
\end{tabular}

Selanjutnya ketika nilai probabilitas transisi pelanggan sudah diketahui maka dapat dilanjutkan ke perhitungan peramalan perpindahan pelanggan dari periode kesatu sampai ke periode kelima. Perhitungan ini menggunakan rumus sebagai berikut: 
$\left(N_{n} M_{n}\right)=\left(N_{n} M_{n}\right) \times$ Matriks Probabilitas Transisi

Perhitungan peramalan perpindahan pelanggan ini dihitung secara manual tidak menggunakan software pendukung. Dari Tabel 6 dapat diketahui bahwa nilai persentase jumlah pelanggan sebesar 63\% atau 0,63 untuk Indomaret. Sedangkan pada Alfamart sebesar 37\% atau 0,37. Jadi dapat dihitung jumlah perpindahan pada periode kedua dengan perhitungan seperti dibawah ini:

$$
\text { Periode } 2=[0,630,37]\left[\begin{array}{cc}
0,68 & 0,32 \\
0 & 1
\end{array}\right]=[0,43 ; 0,57]
$$

Dari perhitungan di atas dapat diketahui bahwa jumlah pelanggan dari Indomaret sebesar 0,43 atau jika dipersentasekan sebesar 43\% sedangkan Alfamart sebesar 0,57 jika dipersentasekan sebesar 57\%. Perhitungan tersebut bisa dibilang cukup akurat apabila pada periode kedua ini dilakukan perhitungan berdasarkan pada jumlah pelanggan diperiode kedua yang ada pada Tabel 5 sebelumnya dan dibuat seperti pada Tabel 6. Pada Tabel 8 dapat dilihat persamaan nilai dengan perhitungan diatas dengan perhitungan berdasarkan pada jumlah pelanggan diperiode kedua yang ada pada Tabel $\mathbf{5}$.

Tabel 8. Data persentase pelanggan periode 2

\begin{tabular}{cccc}
\hline \multirow{2}{*}{ No } & Nama & Jumlah Responden & $\begin{array}{c}\text { Persentase } \\
(\%)\end{array}$ \\
\hline 1. & Indomaret & 15 & $43 \%$ \\
2. & Alfamart & 20 & $57 \%$ \\
& Jumlah & 35 & $100 \%$ \\
\hline
\end{tabular}

Sumber: Kuesioner (2019)

Dengan demikian perhitungan dapat dilanjutkan dari periode kedua sampai periode kelima dengan rumus perhitungan yang sama. Dan hasilnya dapat dilihat jumlah perpindahan dari setiap periode.

$$
\begin{aligned}
& \text { Periode } 3=\left[\begin{array}{ll}
0,43 & 0,57
\end{array}\right]\left[\begin{array}{cc}
0,68 & 0,32 \\
0 & 1
\end{array}\right]=[0,29 ; 0,71] \\
& \text { Periode } 4=\left[\begin{array}{ll}
0,29 & 0,71
\end{array}\right]\left[\begin{array}{cc}
0,68 & 0,32 \\
0 & 1
\end{array}\right]=[0,20 ; 0,80] \\
& \text { Periode } 5=\left[\begin{array}{ll}
0,20 & 0,50
\end{array}\right]\left[\begin{array}{cc}
0,68 & 0,32 \\
0 & 1
\end{array}\right]=[0,14 ; 0,86]
\end{aligned}
$$

Hasil perhitungan di atas selama lima periode dapat dilihat bahwa jumlah pelanggan Indomaret semakin menurun, sedangkan jumlah pelanggan Alfamart semakin meningkat pada tiap periode nya. Hal itu bisa saja terjadi apabila perusahaan yang bersangkutan tidak mengubah strategi pelanggan sebagai salah satu faktor yang bisa mempengaruhi perpindahan pelanggan itu sendiri.

Tabel 9. Data persentase pelanggan periode 1-5

\begin{tabular}{ccccccc}
\hline \multirow{2}{*}{ No } & Nama & Periode & Periode & Periode & Periode & Periode \\
& Franchise & $1(\%)$ & $2(\%)$ & $3(\%)$ & $4(\%)$ & $5(\%)$ \\
\hline 1. & Indomaret & $63 \%$ & $43 \%$ & $29 \%$ & $20 \%$ & $14 \%$ \\
2. & Alfamart & $37 \%$ & $57 \%$ & $71 \%$ & $80 \%$ & $86 \%$ \\
& Jumlah & $100 \%$ & $100 \%$ & $100 \%$ & $100 \%$ & $100 \%$ \\
\hline
\end{tabular}

Sumber: Kuesioner (2019)

Pada Tabel 9 dapat dilihat persentase dari jumlah perpindahan pelanggan selama 5 periode. Dimana pada periode pertama ke periode kedua terjadi perpindahan pelanggan sebesar 0,20 atau 20\%. Dari periode kedua ke periode ketiga sebesar 0,14 atau 14\%. Dari periode ketiga ke periode keempat sebesar 0.09 atau 9\%. Dan dari periode keempat ke periode kelima sebesar 0.06 atau 6\%. Perpindahan pelanggan ini memiliki dampak yang besar bagi kemajuan perusahaan selain itu juga berdampak pada konsistensi perusahaan dalam mempertahankan market share yang telah dimiliki. Jika fenomena ini tidak ditangani secara cepat dan tepat tidak menutup kemungkinan perusahaan dapat mengalami kerugian yang cukup besar.

\section{Kesimpulan}

Penggunaan metode game theory dalam menentukan strategi pelanggan yang terbaik mendapatkan hasil yang optimal. Dari hasil perhitungan kedua mini market yaitu Indomaret dan Alfamart didapatkan metode dengan hasil yang optimum adalah menggunakan metode pure strategy (strategi murni), karena pada metode tersebut hasil maximin = minimax yang menjadikan hasil tersebut sudah optimal. Kemudian, 
dari hasil perhitungannya saddle point pada matrix payoff tersebut yakni terletak pada titik harga dan kelengkapan produk atau $X 5$ dan $X 3$. Karena nilai saddle point nya telah sama yakni nilainya 0 . Dengan demikian diketahui bahwa Alfamart memenangkan strategi pada harga (X5) dan Indomaret memenangkan strategi pada kelengkapan produk (X3).

Sedangkan penggunaan metode markov chain untuk memprediksi perpindahan pelanggan dari kedua mini market tersebut juga membuahkan hasil yang optimal. Dimana dari peramalan dalam lima periode tersebut bahwa Indomaret mengalami penurunan pelanggan atau perpindahan pelanggan dari Indomaret ke Alfamart, hal tersebut terjadi dengan batasan perusahaan tidak mengubah strategi pelanggan selama lima periode tersebut. Maka peramalan tersebut bisa saja terjadi. Persentase perpindahan pelanggan dari periode kesatu ke periode kedua sebesar 20\%. Periode kedua ke periode ketiga sebesar 14\%. Periode ketiga ke periode keempat sebesar 9\%. Dan periode keempat ke periode kelima sebesar 6\%. Pelanggan Alfamart mengalami peningkatan yang signifikan selama 5 periode tersebut, sedangkan pelanggan Indomaret mengalami hal sebaliknya yaitu penurunan yang signifikan selama 5 periode tersebut. Perpindahan pelanggan tersebut bisa diantisipasi dengan menerapkan strategi pelanggan yang sesuai dengan kebutuhan pelanggan.

\section{Daftar Pustaka}

[1] I. Fintikasari and E. Ardyan, "Brand switching behaviour in the generation y: empirical studies on smartphone users," J. Manaj. dan Kewirausahaan, vol. 20 (1), pp. 23-30, 2018, doi: 10.9744/jmk.20.1.23-30.

[2] S. Cameron, "Customer strategy: definition, different types \& retention," bizfluent, 2019. https://bizfluent.com/facts-6940334-customer-strategy-definition.html (accessed Aug. 05, 2021).

[3] H. M. Ritonga, A. P. U. Siahaan, and Suginam "Marketing strategy through markov optimization to predict sales on specific periods," Int. J. for Innovative Research in Multidiciplinary Field, vol. 3 (8), pp. 184-190, 2017, doi: 10.31227/osf.io/z4gsh.

[4] B. Hardjono and L. P. San, "Customer relationship management implementation and its implication to customer loyalty in hospitality industry," J. Din. Manaj., vol. 8 (1), pp. 92-107, 2017, doi: 10.15294/jdm.v8i1.10414.

[5] L. Dewi, "Customer loyalty, through customer satisfaction in customers pt. xyz," J. Apl. Manaj., vol. 18 (1), pp. 189-200, 2020, doi: 10.21776/ub.jam.2020.018.01.19.

[6] N. M. Marliya and Wahyono, "Membangun consumer loyalty melalui social media," 203 Manag. Anal. J., vol. 5 (3), hal. 203-215, 2016.

[7] Y. Indrawati dan N. Untarini, "Pengaruh ketidakpuasan terhadap keputusan perpindahan merek dengan kebutuhan mencari variasi sebagai variabel moderasi," J. Ilmu Manaj., vol. 5 (1), hal. 1-11, 2017.

[8] F. Juliyanto dan E. Y. Sari, "Analisis persaingan perbankan dengan game theory serta upaya meningkatkan kepuasan nasabah dengan pendekatan importance performance analysis," J. Ilm. Tek. Ind., vol. 5 (1), hal. 54-62, 2017, doi: 10.24912/jitiuntar.v5i1.1780.

[9] W. Windasari dan T. Zakiyah, "Analisis game theory pada strategi bersaing grab dan go-jek di Kabupaten Kebumen," PRISMA, Prosiding Seminar Nasional Matematika," vol. 32, hal. 194-198, 2020, [Online]. Available: https://journal.unnes.ac.id/sju/index.php/prisma/.

[10] P. D. Leedy and J. E. Ormrod, Pracical Reseach Planning and Design, Pearson Education Limited, England, 2016.

[11] F. Irina, Metode Penelitian Terapan, Yogyakarta: Parama Ilmu, 2017.

[12] E. Surahman, A. Satrio, dan H. Sofyan, "Kajian teori dalam penelitian," JKTP J. Kaji. Teknol. Pendidik., vol. 3 (1), hal. 49-58, 2020, doi: 10.17977/um038v3i12019p049.

[13] R. Ibnas dan H. K. Musgani, "Aplikasi fuzzy integer transportation dalam optimasi biaya distribusi sepeda motor pada pt. nusantara surya sakti," J. MSA (Mat. dan Stat. serta Apl.), vol. 5 (1), hal. 1423, 2017, doi: 10.24252/jmsa.v5n1p14.

[14] D. R. Indah dan E. Rahmadanni, "Sistem forecasting perencanaan produksi dengan metode single eksponensial smoothing pada keripik singkong srikandi di Kota Langsa," J. Penelit. Ekon. Akutansi, vol. 2 (1), hal. 10-18, 2018.

[15] I. Agustian, H. E. Saputra, dan A. Imanda, "Pengaruh sistem informasi manajamen terhadap peningkatan kualitas pelayanan di pt. jasaraharja putra cabang Bengkulu," Prof. J. Komun. dan Adm. Publik, vol. 6 (1), hal. 42-60, 2019, doi: 10.37676/professional.v6i1.837. 
[16] H. Puspitawati, T. Herawati, dan M. Sarma, "Reliabilitas dan validitas indikator ketahanan keluarga di Indonesia (reliability and validity of family resilience indicators in Indonesia)," J. Kependudukan Indonesia, vol. 13 (1), hal. 1-14, 2018.

[17] M. Devita, "Faktor yang mempengaruhi kinerja karyawan," JOM FISIP, Vol.4 (2), 2017.

[18] M. A. Triandewo and Y. Yustine, "Pengaruh kualitas layanan, citra perusahaan dan kepercayaan pada loyalitas konsumen," J. Bisnis dan Akunt., vol. 22 (1), hal. 13-24, 2020, doi: 10.34208/jba.v22i1.743. 